\title{
Influence of raisins puree on the physicochemical properties, resistant starch, probiotic viability and sensory attributes of coconut milk yogurt
}

\author{
Amirah, A.S., Nor Syazwani, S., *Radhiah, S., Anis Shobirin, M.H., Nor-Khaizura, \\ M.A.R., Wan Zunairah, W.I. and Nurul Shazini, R. \\ Faculty of Food Science and Technology, Universiti Putra Malaysia, 43400 UPM Serdang, Selangor, \\ Malaysia
}

\begin{abstract}
Article history:
June 2019

2019

Keywords:

Yogurt,

Coconut milk,

Raisins puree,

Prebiotic,

Probiotic
\end{abstract}

Received: 10 May 2019

Received in revised form: 21

Accepted: 24 June 2019

Available Online: 9 August

\section{DOI:}

https://doi.org/10.26656/fr.2017.4(1).185

\begin{abstract}
Coconut milk is a good substitute for dairy milk in yogurt production, so that individuals with lactose intolerance and allergy may enjoy the benefits of probiotics in the yogurt. Addition of raisins puree in coconut milk yogurt will further enhance the probiotic viability and increase the prebiotics in yogurt. The objective of the research was to study the physicochemical properties, resistant starch, probiotic viability and sensory acceptance of coconut milk yogurt (CY) supplemented with raisin puree at different levels $(0 \%, 17 \%$, $23 \%$ and $29 \%$ ). Using a commercial dairy yogurt milk (DY) as a comparison, CY with 0 , 17,23 and $29 \%$ raisins puree were characterized by $\mathrm{pH}$, viscosity, total soluble solids, and colour. The nutritional properties were characterized by proximate analysis and resistant starch. The probiotic viability and sensory evaluation were also carried out. As compared to DY, increased level of raisins puree in CY showed significantly higher viscosity, total soluble solid, fat, probiotic viability and resistant starch, but lower protein content. The lightness of $\mathrm{CY}$ decreased with increasing raisins puree amount, whereas redness and yellowness decreased. Sensory evaluation showed that all CY had a better preference in terms of aroma, taste and overall acceptability. Except for CY with $29 \%$ raisins puree, the texture of DY was more preferred over CY. The study suggests that CY with $29 \%$ raisins puree is suitable to improve the overall physical and nutritional properties. Besides, it had significantly better sensory acceptance than DY that makes it a good alternative yogurt for lactose intolerance and milk-allergic individuals.
\end{abstract}

\section{Introduction}

Health, ethics, sustainability or lifestyle issues are the factors that may influence animal-based product exclusions (Hickisch et al., 2016), including yogurt. Yogurt contains probiotics (lactic acid bacteria and bifidobacteria) with health benefits such as improving intestinal microbial balance, cure disordered digestion system, treat body ailments, and prevent gastrointestinal, respiratory, constipation, diarrhoea and urogenital tracks (Ranadheera et al., 2010; Bajaj et al., 2015). Unfortunately, the main ingredient of yogurt is dairy milk, which will affect an individual's choice with lactose intolerance, allergy, or simply vegan. Hence, the substitution of dairy milk in yogurt with lactose-free and healthy ingredient, such as coconut milk is a good alternative.

Coconut milk is milky white oil-in-water emulsion obtained from coconut kernel product with major components of water and fats (Tansakul and
Chaisawang, 2006). Coconut milk is used in bakeries, biscuits, ice creams and confectionaries to enhance flavour and aroma (Sanful, 2009). It is easily digestible because more than $50 \%$ of the fat is medium chain triglycerides from fatty acids. Coconut milk also contains calcium, phosphorus, potassium, vitamins $\mathrm{C}, \mathrm{E}$ and $\mathrm{B}$; glutamic acid, aspartic acid, arginine and antioxidants. Yuliana et al., 2010). In addition, it provides antigen, restores spleen; and prevent rickets and arteriosclerosis (Belewu and Belewu, 2007; Kolapo and Olubamiwa, 2012; Zhu et al., 2014; Huang et al., 2016).

Coconut milk replacing dairy milk was attempted in yogurt (Siripanporn et al., 2000) and fermented ice cream (Aboulfazli et al., 2016). Coconut milk yogurt was stable without syneresis for 14 days when stored at 4 $-10^{\circ} \mathrm{C}$, whereas the texture of coconut milk yogurt had higher panelists score than dairy milk (Siripanporn et al., 2000). Storage of fermented coconut milk ice cream at $20^{\circ} \mathrm{C}$ for 90 days, showed the highest survival of Lactobacillus acidophilus. The fermented coconut milk 
ice cream was also better accepted as compared to fermented soymilk ice cream (Aboulfazli et al., 2016).

To further enhance the nutrition and health properties of yogurt, the addition of raisin is proposed because of its rich nutrients. Raisins (Vitis vinifera L.) or dried grapes contain a high amount of dietary fibre including resistant starch, vitamins and minerals (Ostry et al., 2002). Fructo-oligosaccharides in raisins provide $10 \%$ of daily required dietary fibre, prevent constipation and diarrhea; protect liver function and act as a prebiotic source in food (Dahl and Stewart, 2015). Prebiotics promotes the growth of probiotics by supplying sugar to lactic acid bacteria. It can be fermented by large intestine microbiota and provide selective microbiota which can give health-promoting effects (Figueroa-González, 2011). Resistant starch, which is defined as starch that is not absorbed by the small intestine of healthy individuals (Delcour and Eerlingen, 1995), also gives prebiotic effects on the overall gut health. Other than that, polyphenols mainly flavonols (quercetin and kaempferol) that are available in dried grapes, can help to prevent cancer, coronary heart diseases and aids in antioxidant properties (Yao et al., 2004).

Most research was limited to only replacing milk with coconut milk (Siripanporn et al. 2000; Aboulfazli et al., 2016) or enrich dairy yogurt with dietary fibre that acts as prebiotics (Aportela-Palacios et al., 2005; Hashim et al., 2009; Hoppert et al., 2012; Sah et al., 2016; Bosnea et al., 2017). It is of interest to study the effect of combining fibre source with coconut milk in yogurt. Therefore, by supplementing raisins puree into coconut milk yogurt, it was expected to improve the nutritional values and resistant starch, other than gives benefits to vegetarians and also lactose intolerant individuals. Hence, the objectives of this study were to determine the physicochemical properties and sensory acceptance of coconut milk yogurt supplemented with raisins puree.

\section{Materials and methods}

\subsection{Materials}

Coconut milk (Ayam Brand, Malaysia), coconut water (Karta, Malaysia), sugar and salt were obtained from the local market. The coconut milk contained $2.2 \%$ protein and $20.5 \%$ fat. The probiotics supplement $\left(21^{\text {st }}\right.$ Century, UK) purchased at a local drugstore was used as a starter culture which contained Lactobacillus acidophilus $\left(10^{9} \mathrm{CFU} / \mathrm{mL}\right)$, Lactobacillus salivarius $\left(10^{9}\right.$ $\mathrm{CFU} / \mathrm{mL})$, Bifidobacterium bifidum $\left(10^{9} \mathrm{CFU} / \mathrm{mL}\right)$ and Streptococcus thermophiles $\left(10^{9} \mathrm{CFU} / \mathrm{mL}\right)$. Commercial dairy yogurt (Nestle, Malaysia) was used as control. All chemicals used were food grade.

\subsection{Raisins puree preparation}

Raisins were soaked with distilled water with a ratio of $1: 1$ for $7 \mathrm{hrs}$ at room temperature, ground into a puree, then steamed at $60^{\circ} \mathrm{C}$ for 30 mins (Vijaya et al., 2015).

\subsection{Coconut milk yogurt preparation}

A total of four coconut milk yogurt supplemented with raisins puree formulation (Table 1) were prepared. Coconut milk, sugar, salt and xanthan gum were mixed until fully dissolved. Then, starter culture was added, stirred well, and incubated at $40^{\circ} \mathrm{C}$ for $18 \mathrm{hrs}$. The coconut milk yogurt was then combined with coconut water and mixed for 2 mins until homogeneous. Except for control $(0 \%)$, raisins puree was added into coconut milk yogurt, mixed well and placed in an airtight container. The containers were stored at $4{ }^{\circ} \mathrm{C}$ for $15 \mathrm{hrs}$ before further analysis.

Table 1. Formulation of coconut milk yogurt and coconut milk yogurt supplemented with $0 \%, 17 \%, 23 \%$ and $29 \%$ of raisins puree.

\begin{tabular}{lcccc}
\hline \multirow{2}{*}{ Ingredients $(\mathrm{g})$} & \multicolumn{4}{c}{ Amount of Raisins Puree (\%) } \\
\cline { 2 - 5 } & 0 & 17 & 23 & 29 \\
\hline Coconut milk & 337.64 & 337.64 & 337.64 & 337.64 \\
Sugar & 53.18 & 53.18 & 53.18 & 53.18 \\
Salt & 0.04 & 0.04 & 0.04 & 0.04 \\
Xanthan gum & 0.82 & 0.82 & 0.82 & 0.82 \\
Starter culture & 1.76 & 1.76 & 1.76 & 1.76 \\
Coconut water & 17.77 & 17.77 & 17.77 & 17.77 \\
Raisins puree & - & 82.25 & 123.38 & 164.5 \\
\hline
\end{tabular}

\subsection{Physical measurements}

The $\mathrm{pH}$ values and viscosity were measured in triplicates using a $\mathrm{pH}$ meter digital Model 320, MettlerToledo Ltd., (Esex, UK) and Rheometer (Anthon Paar, USA), respectively.

Colour was determined by transferring $20.0 \mathrm{~mL}$ of yogurt samples into a $1.0 \mathrm{~cm}$ path length quartz cell of Ultrascan Hunter Lab Spectrocalorimetric from Hunter Associate Laboratiry Inc. (Restron, USA). The data was analysed using EasyMatch QC data System software and expressed as L for lightness (from white to black), a for $\mathrm{red} /$ green coordinate (from +red to - green) and $\mathrm{b}$ for yellow/blue coordinate (from +yellow to -blue).

Total soluble solid was measured using refractometer (Master, Japan) and expressed as ${ }^{\circ}$ Brix value.

\subsection{Proximate analysis}

The moisture, ash, protein, fat and fibre contents were analysed based on AOAC Method 934.01, AOAC Method 942.05, AOAC Method 991.20, AOAC Method 989.05 and AOAC Method 978.10, respectively (AOAC, 2006). Resistant starch was determined by resistant 
starch kit from Megazyme (Wicklow, Ireland) that followed the procedure of AOAC Method 2002.02, with a modification to incubation time (Shukri and Shi, 2015).

\subsection{Probiotic viability}

DeMan-Rogosa-Sharpe (MRS) agar was used to grow lactic acid bacteria. Series of dilution using peptone water were prepared by aseptically removing the diluent of culture until the dilution factor determined in the preliminary test was achieved. Using the spread plate method, $0.1 \mathrm{~mL}$ of sample was transferred onto the agar. All the inoculated agar plates were left to incubate with AnaeroGen Sachet at $37^{\circ} \mathrm{C}$ for $72 \mathrm{hrs}$. The colonies were counted using a colony counter (Galaxy 230, Victoria, Australia) and expressed as $\mathrm{CFU} / \mathrm{mL}$. The enumeration was done in duplicates.

\subsection{Sensory evaluation}

The hedonic test was used to determine the degree of sensory acceptance for coconut milk yogurt supplemented with raisins puree. Forty untrained panellists were given $10.0 \mathrm{~g}$ of each sample. The samples were evaluated for aroma, texture, taste and overall acceptability based on a nine-point hedonic scale $(1=$ dislike extremely, $5=$ either like or dislike, $9=$ like extremely).

\subsection{Statistical analysis}

Data were statistically analyzed using Minitab 16 (Minitab Inc. USA) by analysis of variance (ANOVA), and the values were expressed as mean \pm standard deviation from 2 replicates, unless stated otherwise, to determine the significant differences among means for all testing at $\mathrm{p}$ less than 0.05 .

\section{Results and discussion}

\subsection{Physical properties}

The $\mathrm{pH}$, titratable acidity, viscosity, Brix value and colour for dairy milk yogurt (DY) and coconut milk yogurt $(\mathrm{CY})$ are presented in Table 2. DY showed a $1.4 \%$ lower $\mathrm{pH}$ than $\mathrm{CY} 0$ but was statistically significant. The $\mathrm{pH}$ value of $\mathrm{CY}$ decreased with increment of raisins puree (4.20-4.24), probably due to $60-70 \%$ sugar (USDA Nutrient Database, 2018) in raisins puree that was used as a substrate by the cultures. Microorganisms prefer glucose in sugar over lactose (in dairy milk) because it is easier to metabolize (Samona and Robinson, 1994), which in turn promoted the growth of probiotic and lactic acid production, hence lowering the $\mathrm{pH}$. Dairy milk yogurt containing raisins stored for 60 days was reported having lower $\mathrm{pH}$ (3.96) than yogurt containing apples (4.02) or wheat grains (4.04) (Bosnea et al., 2017).

For both viscosity and total soluble solid, CY0 had higher values than DY, which were $10.52 \%$ and $14.45 \%$, respectively. Although xanthan gum increased the firmness of the yogurt and caused higher viscosity (ElSayed et al., 2002), the amount of raisins puree added into $\mathrm{CY}$ played a more prominent role in affecting the viscosity (Table 2). The viscosity of CY supplemented with raisins puree (39.33-55.27 MPa) increased 30-50\% more than CY0 (25.57 MPa) which could be explained by the increased protein interaction with the added sugar (He et al., 2011) from the raisins puree. As raisins puree increased, total soluble solid of $\mathrm{CY}$ also increased probably due to raisins containing cellulosic materials and $60-70 \%$ of total sugar (USDA Nutrient Database, 2018).

Table 2 also shows the colour value, namely lightness $\left(\mathrm{L}^{*}\right)$, redness $\left(\mathrm{a}^{*}\right)$ and yellowness $\left(\mathrm{b}^{*}\right)$ of the yogurt. For $\mathrm{L}^{*}$ and $\mathrm{b}^{*}, \mathrm{CY0}$ had significantly lower values than DY as much as $48 \%$ and $84 \%$, respectively. The result was expected because heat-treated milk used in yogurt production had a lighter hue as a consequence of $\beta$-lactoglobulin denaturation and its conjugation to $\kappa$ casein (Burton, 1994). Compared to CY0, increasing raisins puree in $\mathrm{CY}$ caused significantly higher $\mathrm{a}^{*}$ and $\mathrm{b}^{*}$; as well as lowering of $\mathrm{L}^{*}$, which were contributed by raisins brown hue. Non-enzymatic and/or enzymatic

Table 2. Physical properties of coconut milk yogurt and coconut milk yogurt supplemented with 0\% (CY0), 17\% (CY17), 23\% (CY23) and 29\% (CY29) of raisins puree.

\begin{tabular}{|c|c|c|c|c|c|}
\hline & DY & CY0 & CY17 & CY23 & CY29 \\
\hline $\mathrm{pH}$ & $4.27 \pm 0.01^{\mathrm{b}}$ & $4.33 \pm 0.02^{\mathrm{a}}$ & $4.24 \pm 0.02^{b}$ & $4.19 \pm 0.02^{c}$ & $4.20 \pm 0.01^{\mathrm{c}}$ \\
\hline Viscosity (MPa) & $24.67 \pm 0.40^{\mathrm{c}}$ & $27.57 \pm 2.37^{\mathrm{c}}$ & $39.33 \pm 3.95^{b}$ & $49.77 \pm 0.42^{\mathrm{a}}$ & $55.27 \pm 0.42^{a}$ \\
\hline Total soluble solid ( $\left.{ }^{\circ} \mathrm{Brix}\right)$ & $11.13 \pm 0.12^{\mathrm{e}}$ & $13.01 \pm 0.12^{\mathrm{d}}$ & $15.30 \pm 0.44^{\mathrm{c}}$ & $16.73 \pm 0.29^{b}$ & $18.60 \pm 0.36^{\mathrm{a}}$ \\
\hline \multicolumn{6}{|l|}{ Colour } \\
\hline L* (Lightness) & $86.92 \pm 0.51^{\mathrm{a}}$ & $44.95 \pm 1.89^{b}$ & $34.13 \pm 1.50^{\mathrm{c}}$ & $31.69 \pm 1.11^{\mathrm{d}}$ & $30.46 \pm 1.08$ \\
\hline $\mathrm{a}^{*}$ (Redness) & $1.13 \pm 0.02^{\mathrm{b}}$ & $1.04 \pm 0.03^{\mathrm{b}}$ & $2.49 \pm 0.13^{\mathrm{a}}$ & $2.65 \pm 0.11^{\mathrm{a}}$ & $2.74 \pm 0.14^{\mathrm{a}}$ \\
\hline $\mathrm{b}^{*}$ (Yellowness) & $14.54 \pm 0.51^{\mathrm{a}}$ & $2.36 \pm 0.14^{\mathrm{c}}$ & $2.81 \pm 0.37^{\mathrm{c}}$ & $4.82 \pm 0.30^{b}$ & $4.84 \pm 0.34^{\mathrm{b}}$ \\
\hline
\end{tabular}

Values are expressed as means \pm standard deviation. Means \pm S.D with the same alphabet superscript in the column are not significantly different $(\mathrm{p}<0.05)$ 
reactions during grape rehydration caused gradual brown pigments formation of raisins (Figueiredo-González et al., 2013). Yellow/blue colour was proven to increase during raisining (the process of grapes turning into raisins) (Figueiredo-González et al., 2013), thus increasing the intensity of yellow $\left(b^{*}\right)$ in raisins pureeenriched $\mathrm{CY}$.

\subsection{Nutritional properties}

The moisture, ash, protein, fat and fibre contents in DY and CY are shown in Table 3. All CY had slightly lower moisture and $81 \%$ higher fat as compared to DY. Coconut milk contains $90 \%$ of saturated fatty acid with major medium chain fatty acids such as lauric acid, capric acid and caprylic acid. Higher fat is often associated with higher viscosity (Peamprasart and Chiewchan, 2006), as indicated by higher viscosity of CY (Table 2). Akoma et al. (2000) obtained a similar result where coconut milk yogurt had $15 \%$ more crude fat than dairy milk yogurt. In this study, there was no significant difference between all CY, suggesting that the amount of raisins puree added up to $29 \%$ did not lower the fat content. Although the fat content in CY was significantly higher than DY, fat in coconut may not lead to heart diseases, even consumed over $60 \%$ from calorie intake because coconut has phytocompounds that may enhance the health benefits (Lekshmi et al., 2016). Besides, the lauric acid in coconut oil is easily transferred to the liver to be converted into energy rather than stored as fat (Dayrit, 2015).

For ash content, DY and CY showed no significant difference. The nutrition information on the packaging of DY reported having sodium and calcium as the main mineral. However, dairy milk is also rich in potassium, chloride and phosphorus (Lindmark-Månsson et al., 2003), whereas the main minerals in coconut milk were phosphorus, calcium and potassium (Anon, 1984). Ash contents of DY and CY0 were slightly higher than ash reported in dairy milk (Lindmark-Månsson et al., 2003) and canned coconut milk (Arumughan et al., 1993), respectively. Among CY, ash increased with an increasing amount of raisins puree added. However, only ash in CY29 was $13 \%$ significantly higher than CY0, probably due to the highest amount of puree added that contained higher minerals (Lorenzo et al., 2016).

All CY had comparable protein value, whereas DY had $67-68 \%$ higher protein than other formulations. This result contradicted with the value obtained by Akoma et al. (2000) where crude protein of coconut milk yogurt was slightly higher $(3.78 \%)$ as compared to cow milk yogurt (3.22\%). The difference could be due to a different kind of coconut variety used by Akoma et al. (2000). Another possible reason was, heat treatment and homogenizing process of coconut milk may damage the protein by denaturation (Sfakianakis et al., 2015). Addition of raisins puree did not affect the protein content in the yogurt, as indicated by the similar protein content in all $\mathrm{CY}$.

Crude fibre of DY and coconut milk yogurt is shown in Table 3. Typically, dairy milk and coconut milk contained a negligible amount of fibre, hence the very low value reported in DY and CY0. The crude fibre analysis was however carried out to observe the effect of incorporating raisins puree in $\mathrm{CY}$, due to the fact that raisin was reported to have $3.3-3.9 \%$ insoluble fibre consisting of cellulose, hemicellulose, pectin and lignin (Camire and Dougherty, 2003). All yogurt showed low fibre $(<0.15 \%)$ with no significant differences among samples. The raisins that were pureed may play a role where smaller particles size after grinding may increase the raisins' surface of area to be hydrolyzed, hence the lower fibre. Although insignificant, raisins puree showed a prominent effect on $\mathrm{CY}$ fibre at $23 \%$ inclusion onwards. With an increased amount of raisins puree, the fibre content also increased insignificantly about $63 \%$

Table 3. Nutritional properties and sensory evaluation of coconut milk yogurt and coconut milk yogurt supplemented with $0 \%$ (CY0), 17\% (CY17), 23\% (CY23) and 29\% (CY29) of raisins puree.

\begin{tabular}{lccccc}
\hline & DY & CY0 & CY17 & CY23 & CY29 \\
\hline Moisture (\%) & $61.87 \pm 0.07^{\mathrm{a}}$ & $61.16 \pm 0.24^{\mathrm{b}}$ & $60.89 \pm 0.19^{\mathrm{bc}}$ & $60.54 \pm 0.26^{\mathrm{c}}$ & $60.59 \pm 0.24^{\mathrm{bc}}$ \\
Fat (\%) & $3.10 \pm 0.14^{\mathrm{b}}$ & $16.09 \pm 0.44^{\mathrm{a}}$ & $14.22 \pm 1.77^{\mathrm{a}}$ & $13.26 \pm 1.52^{\mathrm{a}}$ & $15.42 \pm 1.36^{\mathrm{a}}$ \\
Ash (\%) & $0.96 \pm 0.05^{\mathrm{ab}}$ & $0.86 \pm 0.04^{\mathrm{b}}$ & $0.90 \pm 0.06^{\mathrm{ab}}$ & $0.93 \pm 0.03^{\mathrm{ab}}$ & $0.99 \pm 0.01^{\mathrm{a}}$ \\
Protein (\%) & $4.38 \pm 0.02^{\mathrm{a}}$ & $1.43 \pm 0.08^{\mathrm{b}}$ & $1.38 \pm 0.14^{\mathrm{b}}$ & $1.38 \pm 0.08^{\mathrm{b}}$ & $1.45 \pm 0.18^{\mathrm{b}}$ \\
Fibre (\%) & $0.05 \pm 0.02^{\mathrm{a}}$ & $0.09 \pm 0.08^{\mathrm{a}}$ & $0.08 \pm 0.04^{\mathrm{a}}$ & $0.13 \pm 0.08^{\mathrm{a}}$ & $0.13 \pm 0.15^{\mathrm{a}}$ \\
Sensory Evaluation & & & & & \\
Aroma & $2.21 \pm 2.21^{\mathrm{b}}$ & $4.58 \pm 2.42^{\mathrm{ab}}$ & $5.03 \pm 2.18^{\mathrm{a}}$ & $5.25 \pm 2.15^{\mathrm{a}}$ & $5.25 \pm 2.11^{\mathrm{a}}$ \\
Texture & $6.00 \pm 1.22^{\mathrm{a}}$ & $4.93 \pm 0.94^{\mathrm{b}}$ & $4.75 \pm 1.03^{\mathrm{b}}$ & $4.83 \pm 1.01^{\mathrm{b}}$ & $5.93 \pm 1.25^{\mathrm{a}}$ \\
Taste & $2.90 \pm 2.25^{\mathrm{b}}$ & $5.45 \pm 2.09^{\mathrm{a}}$ & $5.88 \pm 1.78^{\mathrm{a}}$ & $6.05 \pm 1.69^{\mathrm{a}}$ & $6.28 \pm 1.62^{\mathrm{a}}$ \\
Overall acceptability & $3.48 \pm 2.26^{\mathrm{b}}$ & $4.98 \pm 2.08^{\mathrm{a}}$ & $5.60 \pm 2.06^{\mathrm{a}}$ & $5.78 \pm 2.01^{\mathrm{a}}$ & $5.83 \pm 2.01^{\mathrm{a}}$ \\
\hline
\end{tabular}

Values are expressed as means \pm standard deviation. Means \pm S.D with the same alphabet superscript in the column are not significantly different $(\mathrm{p}<0.05)$ 
from CY17 to CY23 but remained constant for CY27 and CY29.

\subsection{Resistant Starch}

Figure 1 shows the percentage of resistant starch in DY and CY. All CY were significantly higher than DY. The result was positively correlated with fibre content (Table 3). It is of interest to observe CY0 having significantly higher resistant starch than DY. Although insignificant, resistant starch in CY showed an increasing trend with increment amount of raisins puree. This result was probably due to an increase of fructooligosaccharides and insoluble fibres contributed by raisins puree. Sun-dried raisin was reported to have 5.7\% fructooligosaccharides (Camire and Dougherty, 2003) that escaped small intestine digestion and are fermented by bacteria (specifically bifidobacteria and lactobacilli) in the large intestine (Langlands et al., 2004). Hence, CY incorporated with raisins puree has good potential as a prebiotic source.

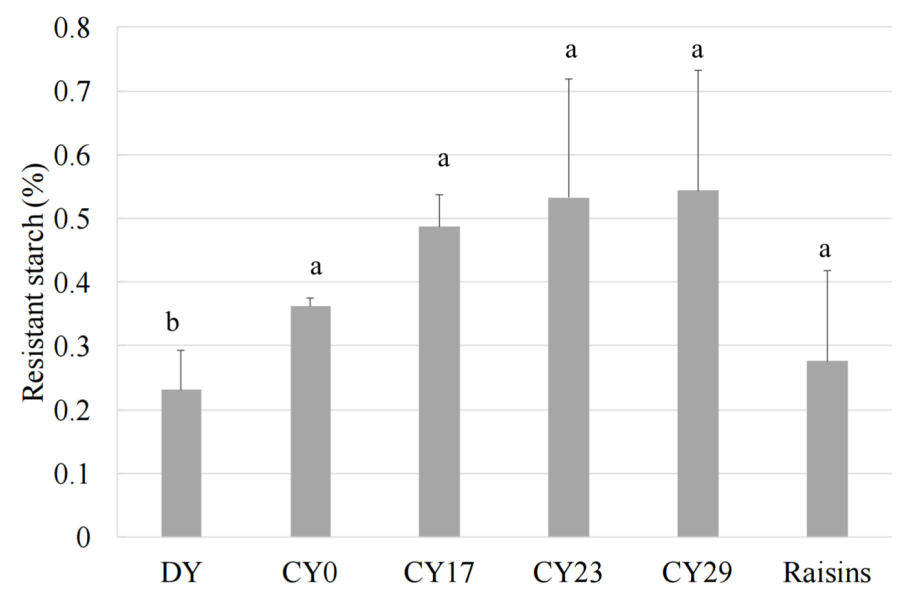

Figure 1. Resistant starch of raisins puree, coconut milk yogurt and coconut milk yogurt supplemented with $0 \%$ (CY0), 17\% (CY17), 23\% (CY23) and 29\% (CY29) of raisins puree. The same alphabet on the top of each bar are not significantly different $(\mathrm{p}<0.05)$.

\subsection{Probiotic viability}

Based on Figure 2, DY had almost tripled the amount of probiotic viability than CY0, most likely due to the high amount of lactose in milk that was available for fermentation and sustainability of probiotics. The probiotic viability in $\mathrm{CY}$ elevated with an increasing amount of incorporated raisins puree, but only the addition of $29 \%$ raisins puree in CY had similar probiotic viability as DY. The probable reason for probiotic viability improvement in CY27 was probably due to the increased amount of fructo-oligosaccharide contained in raisins that enhanced the growth of the probiotic (Tamime, 2007). The resistant starch content in $\mathrm{CY}$ (Figure 1) proved that increased fructooligosaccharides from the incorporation of raisins might act as prebiotics. The nature of prebiotics that are unable to be hydrolyzed in the stomach or small intestine enhanced the growth of probiotics by providing a protective effect through the gastrointestinal tract (Bosnea et al., 2017). Although the resistant starch amount in CY27 was only $0.54 \%$ (Figure 1), the result proved that raisins puree in $\mathrm{CY}$ was able to act as a substrate source to the probiotics, helping to improve the lack of sugar in coconut milk for yogurt fermentation. It is predicted that higher than $27 \%$ of raisins puree may further enhance the probiotic viability in $\mathrm{CY}$.

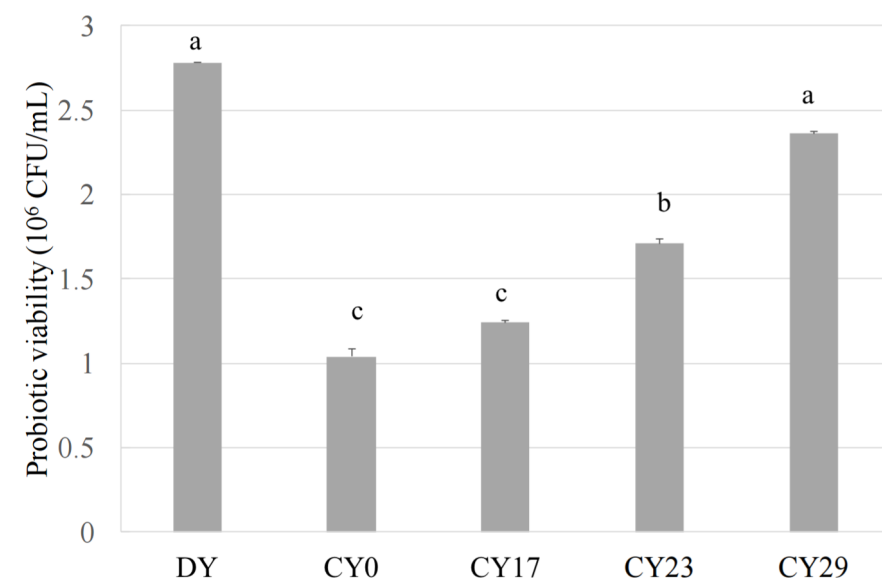

Figure 2. Probiotic viability of coconut milk yogurt and coconut milk yogurt supplemented with 0\% (CY0), 17\% (CY17), 23\% (CY23) and 29\% (CY29) of raisins puree. The same alphabet on the top of each bar are not significantly different $(\mathrm{p}<0.05)$.

\subsection{Sensory evaluation}

The aroma, texture, flavour and overall acceptability of DY and CY are shown in Table 3. In terms of aroma and taste, CY0 had similar sensory acceptance to DY, whereas DY had the highest score for texture, which was similar to that of CY27. The rest of the attributes showed higher scores of all CY than DY. Except for the texture of CY27, all CY showed similar acceptability scores for all attributes. Although insignificant, increasing trends for all attributes of CY were observed with increased added raisins puree. Among all samples, CY29 had the highest scores (ranging between 5 to 6.5) for all sensorial attributes, indicating the most preferred yogurt during the analysis. This result was probably because of $27 \%$ raisins puree in coconut milk yogurt increased the sweetness and improved the overall sensorial experience.

Although the texture score of CY27 was similar to DY, the viscosity of CY27 was the highest (Table 2) among the samples, that may have improved the mouthfeel of the yogurt. This result shows samples with different viscosity may have similar textural acceptance that was probably influenced by the other attributes (aroma and taste). The current result is in conjunction with a study done by Bosnea et al. (2017). The study demonstrated that yogurt enriched with raisins and wheat 
grain were most preferred than yogurt enriched with apple. The panelists in the study also remarked that yogurt enriched with raisins had a special aroma, sweet flavour and coherent texture.

\section{Conclusion}

Addition of raisins puree in $\mathrm{CY}$ increased the viscosity and total soluble solids that may be contributed to mouthfeel experience during sensory, hence improving CY acceptance. The elevated amount of raisins puree in $\mathrm{CY}$ also increased the resistant starch, consequently proving its ability as prebiotic that improved the probiotic viability in CY. Except for texture, all CY had better sensorial scores as compared to DY. We suggest CY29 as the best formulation as an option to replace dairy milk yogurt for lactose intolerance and milk-allergic individuals. Besides, CY29 is suitable to be consumed as a good source of prebiotic and probiotic. Further study on the storage stability of CY would be a further enhancement of the current study.

\section{References}

Aboulfazli, F., Baba, A.S. and Misran, M. (2016). Replacement of bovine milk with vegetable milk: Effects on the survival of probiotics and rheological and physicochemical properties of frozen fermented dessert. International Journal of Dairy Technology, 69(1), 71-80. https://doi.org/10.1111/14710307.12219

Akoma, O., Elekwa. U.O., Afodunrinbi, A.T. and Onyeukwu, G.C. (2000). Yogurt from coconut and tigernuts. Journal of Food Technology in Africa, 5, 132-134. https://doi.org/10.4314/jfta.v5i4.19270

Anon. (1984). 'Coconut cream, raw' NDB no. 12115, Nutrition Data Base. USA: University of Minnesota.

AOAC (2006). Official Methods of Analysis. $17^{\text {th }} \mathrm{ed}$. Gaithersburg: AOAC.

Aportela-Palacios, A., Sosa-Morales, M.E. and VelezRuiz, J.F. (2005). Rheological and physicochemical behaviour of fortified yogurt, with fiber and calcium. Journal of Texture Studies, 36(3), 333-349. https:// doi.org/10.1111/j.1745-4603.2005.00020.x

Arumughan, C., Balachandran, C. and Sundaresan, A. (1993). Development of a process for coconut cream on commercial scale. Journal of Food Science and Technology, 30, 408-412.

Bajaj, B.K., Claes, I.J.J. and Lebeer, S. (2015). Functional mechanisms of probiotics. Journal of Microbiology, Biotechnology and Food Sciences, 4, 321-327. https://doi.org/10.15414/ jmbfs.2015.4.4.321-327

Belewu, M. and Belewu, K. (2007). Comparative physico-chemical evaluation of tigernut, soybean and coconut milk sources. International Journal of Agriculture and Biology, 5, 785-787.

Bosnea, L.A., Kopsahelis, N., Kokkali, V., Terpou, A. and Kanellaki, M. (2017). Production of a novel probiotic yogurt by incorporation of $L$. casei enriched fresh apple pieces, dried raisins and wheat grains. Food and Bioproducts Processing, 102, 6271. https://doi.org/10.1016/j.fbp.2016.11.010

Burton, H. (Ed.) (1994). Chemical and physical changes in milk at high temperatures. In Ultra-HighTemperature Processing of Milk and Milk Products, p. 44-76. New York: Springer Science+Business Media. https://doi.org/10.1007/978-1-4615-2157-0_3

Camire, M.E. and Dougherty, M.P. (2003). Raisin dietary fiber composition and in vitro bile acid binding. Journal of Agriculture and Food Chemistry, 51(3), 834-837. https://doi.org/10.1007/978-1-46152157-0 3

Dahl, W.J. and Stewart, M.L. (2015). Position of the academy of nutrition and dietetics: Health implications of dietary fiber. Journal of the Academy of Nutrition and Dietetics, 115(11), 1861-1870. https://doi.org/10.1016/j.jand.2015.09.003

Daytrit, F.M. (2015). The properties of lauric acid and their significance in coconut oil. Journal of the American Oil Chemists' Society, 92(1), 1-15. https:// doi.org/10.1016/j.jand.2015.09.003

Delcour, J.A. and Eerlingen, R.C. (1995). Formation, analysis, structure and properties of type III enzyme resistant starch. Journal of Cereal Science, 22(2), 129-138. https://doi.org/10.1016/0733-5210(95) 90042-X

El-Sayed, E.M., Abd El-Gawad, I.A., Murad, H.A. and Salah, S.H. (2002). Utilization of laboratoryproduced xanthan gum in the manufacture of yogurt and soy yogurt. European Food Research and Technology, 215(4), 298-304. https:// doi.org/10.1007/s00217-002-0551-9

Figueiredo-González M., Cancho-Grande B. and SimalGándara, J. (2013). Evolution of colour and phenolic compounds during Garnacha Tintorera grape raisining. Food Chemistry, 141(3), 3230-3240. https://doi.org/10.1016/j.foodchem.2013.05.142

Figueroa-González, I., Quijano, G., Ramírez, G. and Cruz-Guerrero, A. (2011). Probiotics and prebiotics - perspectives and challenges. Journal of the Science of Food and Agriculture, 91(8), 13411348. https://doi.org/10.1002/jsfa.4367

Hashim, I.B., Khalil, A.H. and Afifi, H.S. (2009). Quality characteristics and consumer acceptance of yogurt fortified with date fiber. Journal of Dairy 
Science, 92(11), 5403-5407. https://doi.org/10.3168/ jds.2009-2234

Hickisch, A., Bindl, K., Vogel R.F. and Toelstede, S. (2016). Thermal treatment of lupin-based milk alternatives - Impact on lupin proteins and the network of respective lupin-based yogurt alternatives. Food Research International, 89(1), 850-859.

j.foodres.2016.10.013

He, F., Woods, C.E., Litowski, J.R., Roschen, L.A., Gadgil, H.S., Razinkov, V.I. and Kerwin, B.A. (2011). Effect of sugar molecules on the viscosity of high concentration monoclonal antibody solutions. Pharmaceutical Research, 28(7), 1552-1560. https:// doi.org/10.1007/s11095-011-0388-7

Hoppert, K., Zahn, S., Janecke, L., Mai, R., Hoffman, S. and Rohm, H. (2012). Consumer acceptance of regular and reduced-sugar yogurt enriched with different types of dietary fiber. International Dairy Journal, 28(1), 1-7. https://doi.org/10.1016/ j.idairyj.2012.08.005

Huang, J., Liu, X., Lan, Q., Lai, X. and Luo, Z. (2016). Proteomic profile of coconuts. European Food Research and Technology, 242(3), 449-455. https:// doi.org/10.1007/s00217-015-2556-1

Kolapo, A.L. and Olubamiwa, A.O. (2012). Effect of different concentrations of coconut milk on the chemical and sensory properties of soy-coconut milk -based yoghurt. Food and Public Health, 2(4), 8591. https://doi.org/10.5923/j.fph.20120204.01

Langlands, S.J., Hopkins, M.J., Coleman, N. and Cummings, J.H. (2004). Prebiotic carbohydrates modify the mucosa-associated microflora of the human large bowel. Gut, 53(11), 1610-1616. https:// doi.org/10.1136/gut.2003.037580

Lekshmi, S.D., Nazeem, P.A., Narayanankutty, A., Manalil, J.J. and Raghavamenon, A.C. (2016). In silico and wet lab studies reveal the cholesterol lowering efficacy of lauric acid, a medium chain fat of coconut oil. Plant Foods for Human Nutrition, 71 (4), 410-415. https://doi.org/10.1007/s11130-0160577-y

Lindmark-Månsson, H., Fondén, R. and Pettersson, H.-E. (2003). Composition of Swedish dairy milk. International Dairy Journal, 13(6), 409-425. https:// doi.org/10.1016/S0958-6946(03)00032-3

Lorenzo, C.D., Sangiovanni, E., Fumagalli, M., Colombo, E., Frigerio, G., Colombo, F. and Altindi, A. (2016). Evaluation of the anti-inflammatory activity of raisins (Vitis vinifera L.) in human gastric epithelial cells: A comparative study. International Journal of Molecular Science, 17(7), 1156-1156. https://doi.org/10.3390/ijms17071156

Ostry, V., Ruprich, J. and Skarkova, J. (2002). Raisins, ochratoxin A and human health. Mycotoxin Research, 18(Suppl. 2), 178-182. https:// doi.org/10.1007/BF02946091

Peamprasart, T. and Chiewchan, N. (2006). Effect of fat content and preheat treatment on the apparent viscosity of coconut milk after homogenization. Journal of Food Engineering, 77(3), 653-658. https://doi.org/10.1016/j.jfoodeng.2005.07.024

Ranadheera, R.D.C.S., Baines, S.K. and Adams, M.C. (2010). Importance of food in probiotic efficacy. Food Research International, 43(1), 1-7. https:// doi.org/10.1016/j.foodres.2009.09.009

Sah, B.N.P., Vasiljevic, T., McKechnie, S. and Donkor, O.N. (2016). Physicochemical, textural and rheological properties of probiotic yogurt fortified with fibre-rich pineapple peel powder during refrigerated storage. LWT - Food Science and Technology 65, 978-986. https://doi.org/10.1016/ j.lwt.2015.09.027

Samona, A. and Robinson R.K. (1994). Effect of yoghurt cultures on the survival of bifidobacteria in fermented milks. Journal of the Society of Dairy Technology, 47(2), 58-60. https://doi.org/10.1111/ j.1471-0307.1994.tb01273.x

Sanful, R.E. (2009). Promotion of coconut in the production of yoghurt. African Journal of Food Science, 8(3), 147-149. https://doi.org/10.1007/ s11947-014-1412-9

Sfakianakis, P., Topakas, E. and Tzia, C. (2015). Comparative study on high-intensity ultrasound and pressure milk homogenization: effect on the kinetics of yogurt fermentation process. Food and Bioprocess Technology, 8(3), 548-557.

Shukri, R. and Shi, Y.-C. (2015). Physicochemical properties of highly cross-linked maize starches and their enzymatic digestibilities by three analytical methods. Journal of Cereal Science, 63, 72-80. https://doi.org/10.1016/j.jcs.2015.03.001

Siripanporn, J., Maleehual, T., Tammarate, P. and Hengsawadi, D. (2000). Yogurt production from coconut milk. Food, 30, 87-97.

Tamime, D.A. (Ed.) (2007). Prebiotic Ingredients with Emphasis on Galacto-oligosaccharides and Fructooligosaccharides. In Probiotic Dairy Products. $2^{\text {nd }}$ ed., p. 120-137.

Tansakul A. and Chaisawang, P. (2006). Thermophysical properties of coconut milk. Journal of Food Engineering, 73(3), 276-280. https:// doi.org/10.1016/j.jfoodeng.2005.01.035

U.S. Department of Agriculture, Agricultural Research 
Service (USDA). (2018). USDA Nutrient Database for Standard Reference, Release 13. Retrieved on August 2018 from Nutrient Laboratory Homepage website: http://www.nal.usda.gov/fnic/foodcomp

Vijaya K.B., Vijayendra, S.V.N. and Reddy, O.V.S. (2015). Trends in dairy and non-dairy probiotic products - A review. Journal of Food Science and Technology, 52(10), 6112-6124. https:// doi.org/10.1007/s13197-015-1795-2

Yao, L.H., Jiang, Y.M., Shi, J., Tomás-Barberán, F.A., Datta, N., Singanusong, R. and Chen, S.S. (2004). Flavonoids in food and their health benefits. Plant Foods for Human Nutrition, 59(3), 113-122. https:// doi.org/10.1007/s11130-004-0049-7

Yuliana, N., Rangga, A. and Rakhmia. (2010). Manufacture of fermented coco milk drink containing lactic acid bacteria cultures. African Journal of Food Science, 4, 558-562.

Zhu, X., Zhao, Z., Wang, L. and Zhang, L. (2014). Optik a new method to measure fat content in coconut milk based on Y-type optic fiber system. Optik International Journal for Light and Electron Optics, 125(20), 6172-6178. https://doi.org/10.1016/ j.ijleo.2014.06.115 